Research Article

\title{
Improvement of Urinary Stones Analysis Combining Morphological Analysis and Infrared Spectroscopy
}

\author{
Jacopo Gervasoni $\mathbb{D}^{1,2}$ Aniello Primiano, ${ }^{1,2}$ Pietro Manuel Ferraro $\mathbb{D}^{3},{ }^{3}$ Andrea Urbani, ${ }^{1,2}$ \\ Giovanni Gambaro, ${ }^{3}$ and Silvia Persichilli $\mathbb{D D}^{1,2}$ \\ ${ }^{1}$ Istituto di Biochimica e Biochimica Clinica, Università Cattolica del Sacro Cuore, Largo Francesco Vito 1, 00168 Rome, Italy \\ ${ }^{2}$ Area Diagnostica di Laboratorio IRCCS, Fondazione Policlinico Universitario A. Gemelli, Largo Agostino Gemelli 8, 00168 \\ Rome, Italy \\ ${ }^{3}$ Divisione di Nefrologia Complesso Integrato Columbus, Dipartimento di Scienze Mediche, Fondazione Policlinico Universitario \\ A. Gemelli, Università Cattolica del Sacro Cuore, Largo Agostino Gemelli 8, 00168 Rome, Italy
}

Correspondence should be addressed to Jacopo Gervasoni; jacopo.gervasoni@policlinicogemelli.it

Received 9 February 2018; Accepted 4 April 2018; Published 26 April 2018

Academic Editor: Jean-Marie Nedelec

Copyright (C) 2018 Jacopo Gervasoni et al. This is an open access article distributed under the Creative Commons Attribution License, which permits unrestricted use, distribution, and reproduction in any medium, provided the original work is properly cited.

\begin{abstract}
Daudon et al. have developed a complex morphoconstitutional classification of renal stone in six different morphological types and several subtypes. According to this classification, a precise correspondence exists between causes of renal stones and subtypes with a great clinical relevance and can be considering a sort of shortcut for the metabolic diagnosis in renal stone patients. Now the diagnosis of causes of renal stones generally requires repeated biochemical investigations on urine and blood samples and usually remains presumptive. We analyzed 150 urinary stones both by stereoscopic microscopy and Fourier transform infrared spectroscopy. The comparison of 150 stones did not reveal any disagreement. We have only 20 partial agreement, and clinicians agreed that the imprecise information obtained with morphological analysis alone would have missed an important clinical finding only in 3 cases. In conclusion, in our opinion, the analysis of urinary stone must combine two different analytical techniques: morphological analysis by stereomicroscope and biochemical analysis with the FT-IR.
\end{abstract}

\section{Introduction}

Daudon et al. have developed a complex morphoconstitutional classification of renal stones which gives important hints on the pathogenesis of renal stones [1]. This classification is used by other laboratories [2-4]. Six different morphological types of renal stones are identified with several subtypes (Table 1). The crystalline components correspond to specific subtypes, although different subtypes may have the same crystalline component. The associations between different subtypes are also commonly observed in stones, and six main associations have been described by Daudon et al. [1]. According to this classification, a precise correspondence exists between causes of renal stones and subtypes. It is for this correspondence that such a classification would have huge clinical relevance since it would constitute a sort of shortcut in the metabolic diagnosis in renal stone patients. Moreover, it would be a perfect window on the pathogenesis of that specific stone which, otherwise, frequently remains vague. Indeed, now, the diagnosis of causes of renal stones generally requires a number of biochemical investigations on urine and blood samples. Furthermore, due to the variability of many of the parameters, especially those determined in urines, repeated determinations are advocated [5]. Except for the secondary forms of calcium renal stones and for some rare noncalcium stones, the diagnosis of the metabolic causes of a stone remains presumptive. In fact, very rarely, we grasp the metabolic phenomenon determining lithogenesis and stone growth in the precise moment when these phenomena are going on. More frequently, we see some phenomenon occurring months later or earlier of a stone episode. Saying 
TABLE 1: Morphocostitutional classification of renal stones developed by Daudon et al.

\begin{tabular}{|c|c|c|c|}
\hline Morphological type & Subtype & Main components & Common causes \\
\hline \multirow{5}{*}{ I } & Ia & Whewellite & \multirow{5}{*}{$\begin{array}{c}\text { Dietary hyperoxaluria } \\
\text { Stasis, low diuresis } \\
\text { Primary hyperoxaluria type I } \\
\text { Malformative uropathy, stasis and confined multiple } \\
\text { stones } \\
\text { Enteric hyperoxaluria }\end{array}$} \\
\hline & $\mathrm{Ib}$ & Whewellite & \\
\hline & Ic & Whewellite & \\
\hline & Id & Whewellite & \\
\hline & Ie & Whewellite & \\
\hline \multirow{3}{*}{ II } & IIa & Weddellite & \multirow{3}{*}{$\begin{array}{c}\text { Hypercalciuria } \\
\text { Hypercalciuria } \pm \text { hyperoxaluria } \pm \text { hypocitraturia } \\
\text { Hypercalciuria, stasis and confined multiple stones }\end{array}$} \\
\hline & IIb & Weddellite \pm whewellite & \\
\hline & IIc & Weddellite & \\
\hline \multirow{4}{*}{ III } & IIIa & Uric acids & \multirow{4}{*}{$\begin{array}{c}\text { Low urine } \mathrm{pH} \text { and stasis } \\
\text { Metabolic syndrome, diabetes } \\
\text { Hyperuricosuria and alkaline urine, UTI } \\
\text { Hyperuricosuria and diarrhea }\end{array}$} \\
\hline & IIIb & Uric acids & \\
\hline & IIIC & Various urates & \\
\hline & IIId & Ammonium urate & \\
\hline \multirow{5}{*}{ IV } & IVa1 & Carbapatite & \multirow{5}{*}{$\begin{array}{c}\text { Hypercalciuria, UTI } \\
\text { Distal renal tubular acidosis } \\
\text { UTI, hypercalciuria } \\
\text { UTI by urease-splitting bacteria } \\
\text { Hypercalciuria, PHPT, phosphate leak }\end{array}$} \\
\hline & IVa2 & Carbapatite & \\
\hline & $\mathrm{IVb}$ & Carbapatite & \\
\hline & IVc & Struvite & \\
\hline & IVd & Brushite & \\
\hline \multirow{2}{*}{ V } & $\mathrm{Va}$ & Cystine & \multirow{2}{*}{$\begin{array}{c}\text { Cystinuria } \\
\text { Cystinuria }+ \text { inadequate therapy }\end{array}$} \\
\hline & $\mathrm{Vb}$ & Cystine & \\
\hline \multirow{3}{*}{ VI } & VIa & Proteins & \multirow{3}{*}{$\begin{array}{c}\text { Chronic pyelonephritis } \\
\text { Proteinuria, drugs, clots } \\
\text { ESRF and excessive calcium + vitamin D } \\
\text { supplementation }\end{array}$} \\
\hline & $\mathrm{VIb}$ & Proteins & \\
\hline & VIc & Proteins & \\
\hline
\end{tabular}

with CL Smith's words, since "Stones recovered from the urinary tract are like rocks to the archeologist in that their study discloses information regarding their formation" [6], if we are able to classify this information, then we would have a strong diagnostic tool in our hands. Daudon's classification is at the moment the strongest attempt to reach this result.

Grinding the sample for IR analysis is still the main inconvenience because of the loss of spatial distribution of the different minority compounds present in the kidney stone. The location of major and minor components in the stone is of major importance; in fact, the precise point of the stone where each component precipitates is generally linked to the urine conditions at the time of the corresponding solid formation. The metabolic changes whose patients suffer from remain imprinted in the stone, defining a particular distribution of the components. The morphological analysis with stereoscopic microscopy is a technique which gives complementary information to the IR analysis.

For these reason, we would like to introduce, in our laboratory, morphological analysis (MA) to be used together with the IR technology already introduced in routine since 2013 [7].

The aim of our paper was to analyze 150 urinary stones both with infrared spectroscopy and stereoscopic microscopy to underline the usefulness to introduce the analytical methodology known as morphocostitutional analysis and improve the accuracy of urinary stone classification.

\section{Materials and Methods}

We analyzed 150 consecutive urinary stones, from 150 patients (68\% men and 32\% women; age range 29-82) from the Divisions of Nephrology and Urology of our University Hospital.
Stones were washed with deionized water and dried at room temperature for $24 \mathrm{~h}$. After that, for each stone, shape, color, size, and weight were registered. Stones were then analyzed both by stereoscopic microscopy (STEM) and Fourier transform infrared spectroscopy (FT-IR) as described below. When a discordance occurred (less than $10 \%$ of cases), a joint evaluation was performed to share the allocation of cases. This was possible in all discordant cases.

Finally, the clinicians were separately interrogated on how the discrepant results would have modified their diagnostic and therapeutic conclusions.

2.1. FT-IR Analysis. For FT-IR analysis, stones were powdered and mixed with an inert powdered support (dried potassium bromide) in a proportion of 0.5 to $2 \%$ in agate mortar. This mixture was transferred into an appropriate die and pressed at $10 \mathrm{t} / \mathrm{cm}^{2}$ to form a transparent pellet $13 \mathrm{~mm}$ in diameter. The pellet assembled in a holder was placed in the infrared (IR) beam of the spectrometer. The spectral region investigated was from 4000 to $400 \mathrm{~cm}^{-1} ; 32$ scans were averaged with a $4 \mathrm{~cm}^{-1}$ resolution for each spectrum. Background spectra were performed at air or pure KBr pellet before each analysis (sample blank). Spectra were recorded by means of a PerkinElmer Spectrum One [8]. Spectra were then computer-matched with the Euclidean search application, a tool of SPECTRA NICODOM IR Library (obtained from Nicodom s.r.o., Hlavni 2727 CZ-14100 Praha 4, Czech Republic, EU) that compares the unknown spectrum with reference spectra contained in the library between 4000 and $400 \mathrm{~cm}^{-1}$. A report is then generated for the various stone components. The results of the automatic comparison for 
TABLE 2: Composition and agreement in the pure stone group.

\begin{tabular}{lccc}
\hline & Pure stones & & \\
Substances detected $(n)$ & Agreement $(n)$ & Partial agreement $(n)$ & Disagreement $(n)$ \\
\hline Calcium oxalate monohydrate $(47)$ & 44 & 0 & 0 \\
Calcium oxalate dihydrate (1) & 1 & 0 & 0 \\
Carboapatite (1) & 1 & 0 & 0 \\
Anhydrous uric acid (4) & 4 & 0 & 0 \\
Brushite (2) & 2 & 0 & 0 \\
Ammonium urate (1) & 1 & 0 & 0 \\
Cystine (10) & 10 & 0 & 0 \\
Proteins (5) & 5 & $3(4.3 \%)$ & $0(0.0 \%)$ \\
Total $(71)$ & $68(95.7 \%)$ & & 0 \\
\hline
\end{tabular}

spectrum identification were provided as a list of the bestfitting spectra with their scores. The score value can range from 0.000 to 1.000 . Score 1.000 indicates a perfect likeness between the unknown spectrum and the reference one. In each case, a visual inspection of the spectra was performed to check the results and assign the composition.

2.2. Morphological Analysis. MA was conducted in accordance with the protocol published by Daudon et al. [1] (Table 1). The sample analyzed by STEM was observed at different magnifications (from $7.5 \mathrm{x}$ up to $50 \mathrm{x}$ ). After surface observation and identification of subtypes, the stone was sectioned and the identification of subtypes in the core, middle, and outer layers was performed separately. In the case of stones obtained after extracorporeal shock wave lithotripsy (ESWL), all available fragments were studied to determine form and structure. Stones containing two or more components were classified as "mixed stones", and their major and minor components were identified. The cutoff between minor and major components was specified as $<40 \%$. The cutoff for elements in trace was $<5 \%$.

2.3. Method Comparison. On the basis of FT-IR analysis, calculi were divided into three groups: pure stones $(n=71)$, mixed stones $(n=68)$, and pure stones with components in trace $(n=11)$. Results of each group were compared with those obtained with MA.

Classification criteria were established by comparing results obtained with the two methods in reference to the identification of different species as follows:

(i) Agreement: when FT-IR and MA identified the same components

(ii) Partial agreement: when MA identified the main stone component(s) detected by FT-IR but in addition there were some disagreement for secondary constituents

(iii) Disagreement: when MA did not identify the main stone component

\section{Results}

The analysis of 150 stones did not reveal any disagreement. In Tables 2-4, the comparison between the two methods is reported for pure, pure with substances in trace, and mixed stones, respectively. The large agreement in all groups is clearly evident; in fact, only $4.2 \%, 18.1 \%$, and $22.1 \%$ were in partial agreements among pure stones, pure stones with substances in trace, and mixed stones, respectively.

Seventy-one were the pure stones, that is, composed of just one crystalline species (Table 2). The most represented type was calcium oxalate $(\mathrm{CaOx})$ as monohydrate crystal (COM). In this category, we observed 3 discordant cases (\#13, \#18, and \#60); indeed, MA suggested the presence of dihydrate $\mathrm{CaOx}$ (COD) not detected by FT-IR in all three cases. However, this discrepancy could be explained by an intermediate transition form of COD to COM on the stone surface. Thus, there is a reason to consider this finding as congruent with the FT-IR analysis.

In 11 stones, the FT-IR disclosed the presence of a second crystalline species in trace, which was not discovered by the MA in 2 cases (\#84 and \#119) (Table 3). In both, traces of carboapatite were below the cutoff limit for substances in trace.

Sixty-eight were the mixed stones examined, that is, 2 or more components sometimes associated with further components in traces (Table 4). Full agreement between FTIR and MA was observed in 53. The examination of the remaining 20 stones gave discordant results (Table 5). In particular, in \#29, \#67, and \#87, the FT-IR spectroscopy did not identify the COD component which was recognized by the MA; this happened always on the MA of the surface of the stone where the transition of COD to COM was described. Another significant discrepancy occurred in two stones (\#96 and \#100) where dihydrate uric acid crystals were observed by MA at odds of FT-IR which reported only anhydrous crystals.

A number of other cases were discordant for the presence of tiny quantities of some crystalline component which was not identified by MA.

In a $\mathrm{CaOx}$ stone (\#42 and \#90) (COM/COD 70/30\% and $85 / 10 \%$, resp.), the small quantity $(<5 \%)$ of carboapatite was not recognized. Of note, the examined specimen was a fragment of a stone recovered after shock wave lithotripsy.

In specimens \#12 and \#75, both containing a significant quantity of carboapatite (60 and $10 \%$, resp.), a tiny quantity below the cutoff limit $(<5 \%)$ of brushite and/or octacalcium phosphate was also identified by FT-IR spectroscopy. Both were stone fragments obtained after ESWL and ureteroscopy, and ureteroscopy, respectively. 
TABLE 3: Composition and agreement in pure stone with substances in trace group.

\begin{tabular}{|c|c|c|c|}
\hline \multicolumn{4}{|c|}{ Pure stones with substances in trace } \\
\hline Substances detected $(n)$ & Agreement $(n)$ & Partial agreement $(n)$ & Disagreement $(n)$ \\
\hline $\begin{array}{l}\text { Anhydrous uric acid + calcium oxalate monohydrate } \\
\text { trace (1) }\end{array}$ & 1 & 0 & 0 \\
\hline $\begin{array}{l}\text { Calcium oxalate monohydrate }+ \text { calcium oxalate } \\
\text { dihydrate trace }(1)\end{array}$ & 1 & 0 & 0 \\
\hline Carboapatite + struvite $(1)$ & 1 & 0 & 0 \\
\hline Cystine + carboapatite (1) & 1 & 0 & 0 \\
\hline Protein + carboapatite trace $(1)$ & 1 & 0 & 0 \\
\hline Struvite + carboapatite trace $(1)$ & 0 & 1 & 0 \\
\hline Brushite + carboapatite trace (1) & 1 & 0 & 0 \\
\hline Brushite + calcium oxalate monohydrate trace $(2)$ & 2 & 0 & 0 \\
\hline $\begin{array}{l}\text { Calcium oxalate monohydrate }+ \text { carboapatite } \\
\text { trace }(2)\end{array}$ & 1 & 1 & 0 \\
\hline Total (11) & $9(81.8 \%)$ & $2(18.2 \%)$ & $0(0.0 \%)$ \\
\hline
\end{tabular}

TABLE 4: Composition and agreement in the mixed stones group.

\begin{tabular}{|c|c|c|c|}
\hline \multicolumn{4}{|c|}{ Mixed stones } \\
\hline Substances detected $(n)$ & Agreement $(n)$ & Partial agreement $(n)$ & Disagreement $(n)$ \\
\hline $\begin{array}{l}\text { Calcium oxalate monohydrate + calcium oxalate } \\
\text { dihydrate (9) }\end{array}$ & 9 & 0 & 0 \\
\hline $\begin{array}{l}\text { Anhydrous uric acid + calcium oxalate monohydrate } \\
\text { (6) }\end{array}$ & 4 & 2 & 0 \\
\hline $\begin{array}{l}\text { Calcium oxalate monohydrate }+ \text { calcium oxalate } \\
\text { dihydrate }+ \text { carboapatite }(13)\end{array}$ & 11 & 2 & 0 \\
\hline $\begin{array}{l}\text { Anhydrous uric acid }+ \text { dihydrate uric acid + calcium } \\
\text { oxalate monohydrate }(2)\end{array}$ & 1 & 1 & 0 \\
\hline $\begin{array}{l}\text { Calcium oxalate monohydrate }+ \text { calcium oxalate } \\
\text { dihydrate }+ \text { carboapatite }+ \text { brushite }+ \text { octacalcium } \\
\text { phosphate }(1)\end{array}$ & 0 & 1 & 0 \\
\hline $\begin{array}{l}\text { Carboapatite + calcium oxalate monohydrate } \\
+ \text { Whitlockite (1) }\end{array}$ & 0 & 1 & 0 \\
\hline Protein + calcium oxalate monohydrate $(1)$ & 1 & 0 & 0 \\
\hline Cystine + carboapatite $(3)$ & 3 & 0 & 0 \\
\hline $\begin{array}{l}\text { Carboapatite }+ \text { struvite }+ \text { calcium oxalate } \\
\text { monohydrate }(1)\end{array}$ & 0 & 1 & 0 \\
\hline Carboapatite + struvite $(10)$ & 9 & 1 & 0 \\
\hline Carboapatite + struvite + brushite (1) & 1 & 0 & 0 \\
\hline Carboapatite + struvite + ammonium urate (1) & 1 & 0 & 0 \\
\hline Brushite + calcium oxalate dihydrate $(1)$ & 1 & 0 & 0 \\
\hline $\begin{array}{l}\text { Anhydrous uric acid }+ \text { ammonium urate }+ \text { calcium } \\
\text { oxalate monohydrate (1) }\end{array}$ & 0 & 1 & 0 \\
\hline $\begin{array}{l}\text { Anhydrous uric acid + ammonium urate }+ \text { struvite } \\
+ \text { calcium oxalate monohydrate }+ \text { sodium urate }(1)\end{array}$ & 1 & 0 & 0 \\
\hline Ammonium urate + anhydrous uric acid (1) & 1 & 0 & 0 \\
\hline Ammonium urate + carboapatite $(1)$ & 1 & 0 & 0 \\
\hline Calcium oxalate dihydrate + carboapatite $(2)$ & 2 & 0 & 0 \\
\hline $\begin{array}{l}\text { Carboapatite }+ \text { magnesium ammonium } \\
\text { phosphate }(2)\end{array}$ & 2 & 0 & 0 \\
\hline Carboapatite + protein + triglycerides $(1)$ & 0 & 1 & 0 \\
\hline Carboapatite calcium oxalate dihydrate + brushite (1) & 0 & 1 & 0 \\
\hline Calcium oxalate dihydrate + brushite $(1)$ & 1 & 0 & 0 \\
\hline Calcium oxalate monohydrate + carboapatite $(7)$ & 4 & 3 & 0 \\
\hline Total (68) & $53(77.9 \%)$ & $15(22.1 \%)$ & $0(0.0 \%)$ \\
\hline
\end{tabular}

Tiny quantities of COM were also missed by MA in 2 uric acid-containing stones (\#26 and \#128) and in a mixed carboapatite and struvite stone (\#130).
Conclusions for stone \#5 were discordant because FT-IR recognized protein and triglyceride components $(15 \%$ and $<5 \%)$ in these quantities cannot be recognized on MA. The 
TABLE 5: Composition for the 20 discordant results observed by MA and FT-IR.

\begin{tabular}{|c|c|c|c|c|c|c|c|c|c|c|c|c|c|c|c|}
\hline \multirow{2}{*}{ \#Stone } & \multicolumn{3}{|c|}{ MA } & \multicolumn{12}{|c|}{ FT-IR } \\
\hline & Core & Section & Surface & $\mathrm{COM}$ & COD & CARBA & STRU & BRU & AU0 & AU1 & AU2 & AmUr & PROT & OCP & WK \\
\hline 5 & & IVa1 & & & & 85 & & & & & & & 15 & & \\
\hline 12 & IVa1 & IVa1 + IIa & IVa1 & & 40 & 60 & & $<5$ & & & & & & & \\
\hline 13 & & $\mathrm{Ib}$ & IIb--> Ia & 100 & & & & & & & & & & & \\
\hline 18 & Ia & Ia & IIb--> Ia & 100 & & & & & & & & & & & \\
\hline 26 & & IIIa & IIIb & $<5$ & & & & & 50 & & 50 & & & & \\
\hline 29 & & $\mathrm{Ia}+\mathrm{IVa}$ & IIb--> Ia & 95 & & 5 & & & & & & & & & \\
\hline 42 & & Ia & IIb--> Ia & 70 & 30 & $<5$ & & & & & & & & & \\
\hline 60 & & Ia & IIb--> Ia & 100 & & & & & & & & & & & \\
\hline 67 & & $\mathrm{Ia}+\mathrm{IVa}$ & IIb--> Ia & 90 & & 10 & & & & & & & & & \\
\hline 75 & & $\mathrm{Ia}+\mathrm{IVa}$ & IIa & 70 & 20 & 10 & & $<5$ & & & & & & $<5$ & \\
\hline 81 & IVa1 & $\mathrm{Ia}+\mathrm{IVa} 1$ & IVa1 & 10 & & 70 & & & & & & & & & 20 \\
\hline 84 & & Ia & Ia active & 100 & & $<5$ & & & & & & & & & \\
\hline 87 & & $\mathrm{Ia}+\mathrm{IVa}$ & IIb--> Ia & 95 & & 5 & & & & & & & & & \\
\hline 90 & & Ia & IIb--> Ia & 85 & 10 & 5 & & & & & & & & & \\
\hline 96 & Ia & $\mathrm{Ia}+\mathrm{IIIb}$ & IIIb & 50 & & & & & 50 & & & & & & \\
\hline 100 & & Ia & IIIb & 90 & & & & & 10 & & & & & & \\
\hline 119 & & IVc & IVc & & & $<5$ & 100 & & & & & & & & \\
\hline 128 & IIIc & IIIa & & $<5$ & & & & & 70 & & & 30 & & & \\
\hline 130 & & $I V a+I V c$ & $\mathrm{IVa}+\mathrm{IV} \mathrm{c}$ & $<5$ & & 30 & 70 & & & & & & & & \\
\hline 134 & & IVc & IVc & & & 10 & 90 & & & & & & & & \\
\hline
\end{tabular}

COM, monohydrate calcium oxalate; COD, dihydrate calcium oxalate; CARBA, carboapatite; STRU, struvite; BRU, brushite; AU0, uric acid anhydrous; AU1, uric acid monohydrate; AU2, uric acid dehydrate; AmUr, ammonium urate; PROT, protein; OCP, octacalcium phosphate; WK, Whitlockite; IIb--> Ia indicates the transition phase COD to COM in the stone.

analysis of stone \#81 gave discrepant results because it was composed by carboapatite (70\%), COM (10\%), and Whitlockite $(20 \%)$, a calcium phosphate crystal rarely observed in renal stones, that cannot be recognized at MA. Finally, in stone \#134, whose main component was struvite, carboapatite $(10 \%)$ was not recognized.

\section{Discussion}

In this study, we compared the results obtained for 150 urinary stones analyzed using both the FT-IR and stereomicroscopy. As expected, this study confirms the concordance of the morphological subtypes of stones and the crystalline components. In fact, this was observed in 87 to $94 \%$ of cases depending on the conservativeness of the criteria used.

According to the morphoconstitutional classification of Daudon et al. [1], COM is generally associated with hyperoxaluric states, while COD suggests the existence of hypercalciuria. However, since the conversion from COD to the more stable COM crystalline phase is a well-known phenomenon [9], some derangement from this strict dichotomy is expected. In the eight stones which were discordant (the case of $\# 13, \# 18, \# 29, \# 42, \# 60$, \#67, \#87, and \#90 (Table 5)), the disagreement was only observed on the surface of the stone that was most recently formed. Interestingly, the appearance was that of the subtype IIb, that is, a mixture of COD and COM. In this condition, when COD is almost completely converted to COM, the FT-IR signals are difficult to be interpreted and the morphological investigation of the stone for a conclusive definition of the crystalline species is necessary. Not recognizing the COD component in a stone would in theory have stronger clinical implications because of neglecting the frequent association with hypercalciuria. However, in this case, it was the FT-IR not the MA that gave incomplete information, failing to recognize that a certain portion of $\mathrm{CaOx}$ existed in the transition phase COD to COM in the stone.

In two pure stones where FT-IR disclosed trace elements of a second crystalline species (\#84 and \#119; Table 5), MA did not recognize the constituent in trace. Interestingly, stone \#84 was indeed a post-ESWL fragment, and the unrecognized component was carboapatite. The existence in otherwise pure stones of COM of minor quantities, generally less than $10 \%$, of carboapatite is typical of the "idiopathic" $\mathrm{CaOx}$ nephrolithiasis and considered to be a remnant of Randall's plaque on which the stone formed [10]. This once more advises for collecting as much as possible fragments of a stone to perform the analysis of its components. In fact, properly recognizing Randall's plaque residue in a $\mathrm{CaOx}$ stone gives very important and useful pathogenic and diagnostic clues [11]. However, this is not accepted by all, and thus, the idiopathic nature of the $\mathrm{CaOx}$ nephrolithiasis still requires a full diagnostic workup [12].

The second case (\#119) was a stone made of struvite, a structure which forms in an alkaline milieu that also favors carboapatite crystallization.

In mixed stones (Table 4), the presence of minute quantities of brushite $(<5 \%)$ in stones containing carboapatite (\#12 and \#75) is also not unexpected since brushite is considered to be a crystalline precursor of the latter, a clinically useless information [13]. The same for uric acid containing stones \#26 and \#128 which had COM in trace. The presence of $\mathrm{CaOx}$ in a uric acid stone is predicted by the 
promoting role of uric acid on $\mathrm{CaOx}$ crystallization [14]. Finally, the minute percentage of COM in uric acid containing stones (\#26 and \#128) would not change the clinical approach since preventive treatment of uric acid stones certainly does not aggravate the risk of $\mathrm{CaOx}$ lithogenesis.

In our opinion, all stones disclosing at FT-IR spectroscopy tiny quantities $(<5 \%)$ of some crystalline components should not be considered as truly discordant if that component is not described at MA. In fact, not recognizing under the STEM such a tiny quantity of COM is quite comprehensible because probably it existed in a very focal, microscopic location in the stone.

Main discordances were observed in the 2 stones primarily composed by carboapatite, stone \#5 and \#81, in which protein or Whitlockite were recognized, respectively. The stereomicroscopic examination does not consent to identify proteins in a stone if it is scantily represented. It can identify Whitlockite due to the lack of a specific morphology for this rare calcium phosphate component of renal stones. Whitlockite, a calcium magnesium orthophosphate $(\mathrm{Ca}, \mathrm{Mg})_{3}$ $\left(\mathrm{PO}_{4}\right)_{2}$, is generally found in women with stones associated with chronic urinary tract infections by nonureaseproducing bacteria [15]. Proteins are a common constituent of kidney stones, but at marginal concentrations, that is, less than $2.5 \%$ dry weight $[16,17]$. On the contrary, proteins are much more represented in stones associated with chronic urinary infections as likely in this case. Thus, these 2 cases suggest a role of urinary tract infections in their pathogenesis. The condition of the struvite stone \#134 where MA did not reveal $10 \%$ carboapatite could be similar. While the presence of carboapatite could denote the metabolic origin of the stone followed by a super infection causing struvite precipitation [18], an entire infectious origin cannot be discarded. A more in-depth analysis with the determination of the carbonation rate of carboapatite in these stones would support this role [19].

What would be the consequence of the "wrong" diagnosis of stone composition with MA? Finding a relevant quantity of brushite in a stone is an important clinical observation due to the specific profile of patients forming brushite stones, that is, recurrent stone formers who had multiple previous ESWL and who may have converted from another stone composition [13, 20]. These patients have hypercalciuria but not distal renal tubular acidosis and primary hyperparathyroidism [13]. Furthermore, they may have obstruction of the urinary tract, either congenital or acquired [21]. Even the main discordance observed in stones \#96 and \#100 where dihydrate uric acid crystals were observed by MA at odds of anhydrous uric acid recognized by FT-IR has a minor if not irrelevant clinical meaning. Actually, both crystalline forms are due to conditions characterized by low urine $\mathrm{pH}[22]$.

The microscopic analysis of composition of different areas (core, middle layer, and surface) of urinary stone permit to understand urinary stone genesis and to know the origin of this event allowing, together to FT-IR analysis, a more targeted clinical intervention for reducing the risk of recurrence.

According to morphological characterization of Daudon, COM urinary stones are divided into five subtypes
(Ia, Ib, Ic, Id, and Ie), each of them associated with different etiologies [1], and then, the identification of specific subtype, not possible with IR analysis, helps to reach the correct diagnosis. For instance, we have identified some renal stones as subtype Ie with STEM and pure COM with FT-IR. The subtype Ie is associated with enteric hyperoxaluria and in all these cases clinicians have confirmed inflammatory bowel diseases (IBD) for these patients. It is clear that an uncommon subtype like Ie can be very useful for the clinician in order to diagnose a severe cause of hyperoxaluria, often responsible of chronic kidney disease and end-stage kidney disease (ESKD) [23] and not always previously identified with other diagnostic investigations.

Another example that underlines the importance of morphological analysis can be seen in calcium phosphate kidney stones, which constitutes a very heterogeneous group and are divided into five morphological subtypes (IVa1 and IVa2 and IVb, IVc, and IVd) each of them associated with multiple etiologies, including urinary tract infection and/or different metabolic disorders.

As it was reported in the study carried out by Daudon et al. [24], infrared spectra of the subtypes IVa1 and IVa2, both composed of carbonate apatite $\left(\mathrm{Ca}_{5}\left(\mathrm{PO}_{4}\right)_{3} \mathrm{OH}\right)$, are similar, but the two subtypes have different morphological structures. The first subtype (IVa1) has a homogeneous rough surface and a poorly organized section of diffuse. The second subtype (IVa2) shows a peculiar morphology characterized by smooth surface with glazed appearance and small cracks.

Type IVa1 is observed in case of urinary tract infection (UTI) and in patients with idiopathic hypercalciuria, while type IVa2 was associated with $90 \%$ all cases with distal renal tubular acidosis (dRTA).

Indeed, in our study, for a stone type IVa2, the clinicians have confirmed the diagnosis made with STEM analysis. It is obvious that such detailed information can be very helpful in addressing clinical diagnosis.

FT-IR technique shows a high sensitivity and allows an accurate identification of stone composition, but it cannot discriminate into different subtypes. The advantage of adding a stone morphology examination to infrared analysis is to provide a rapid, inexpensive orientation to specific pathological conditions that could not be readily identified when extensive metabolic investigations are not systematically performed.

Renal stone analysis should be able to identify, in a standardized way, all the characteristics that show a correlation with the etiopathogenesis of the disease: chemical composition, crystalline species, morphological characteristics, the sequence of precipitation of the components, and relative amounts of each of them. No analytical technique taken individually is able to provide all these information. For these reasons, a specialized center in the analysis of urinary stone must combine two different analytical techniques: morphological analysis by stereomicroscope, to determine the morphological characteristics and the precipitation sequence of components, and biochemical analysis with the FT-IR, for the determination and quantification of the individual components. 


\section{Ethical Approval}

No animals were included in the study. All procedures performed in this study involving human participants were in accordance with the ethical standards of the institutional and/or national research committee and with the 1964 Helsinki Declaration and its later amendments or comparable ethical standards.

\section{Disclosure}

Aniello Primiano is the co-first author.

\section{Conflicts of Interest}

None of the authors have any potential conflicts of interest.

\section{References}

[1] M. Daudon, A. Dessombz, V. Frochot et al., "Comprehensive morpho-constitutional analysis of urinary stones improves etiological diagnosis and therapeutic strategy of nephrolithiasis," Comptes Rendus Chimie, vol. 19, no. 11-12, pp. 1470-1491, 2016.

[2] S. Gràcia-Garcia, F. Millán-Rodríguez, F. Rousaud-Barónb et al., "Why and how we must analyze urinary calculi," Actas Urológicas Españolas, vol. 35, no. 6, pp. 354-362, 2011.

[3] S. F. Silva, D. C. Matos, S. L. Silva, F. Daher Ede, H. Campos Hde, and C. A. Silva, "Chemical and morphological analysis of kidney stones. A double-blind comparative study," Acta Cirurgica Brasileira, vol. 25, no. 5, pp. 444-448, 2010.

[4] A. Alaya, M. Belgith, S. Hammadi, A. Nouri, and M. F. Najjar, "Kidney stones in children and teenagers in the central coast region of Tunisia," Iranian Journal of Pediatrics, vol. 22, no. 3 , pp. 290-296, 2012.

[5] J. H. Parks, E. Goldfisher, J. R. Asplin, and F. L. Coe, "A single 24-hour urine collection is inadequate for the medical evaluation of nephrolithiasis," Journal of Urology, vol. 167, no. 4, pp. 1607-1612, 2002.

[6] C. L. Smith, "Renal stone analysis: is there any clinical value?," Current Opinion in Nephrology and Hypertension, vol. 7, no. 6, pp. 703-709, 1998.

[7] A. Primiano, S. Persichilli, G. Gambaro et al., "FT-IR analysis of urinary stones: a helpful tool for clinician comparison with the chemical spot test," Disease Markers, vol. 2014, Article ID 176165, 5 pages, 2014.

[8] L. M. Estepa, P. Levillain, B. Lacour, and M. Daudon, "Infrared analysis of urinary stones: a trial of automated identification," Clinical Chemistry and Laboratory Medicine, vol. 37, no. 11-12, pp. 1043-1052, 1999.

[9] D. Bazin, C. Leroy, F. Tielens et al., "Hyperoxaluria is related to whewellite and hypercalciuria to weddellite: what happens when crystalline conversion occurs?," Comptes Rendus Chimie, vol. 19, no. 11-12, pp. 1492-1503, 2016.

[10] S. R. Khan, M. S. Pearle, W. G. Robertson et al., "Kidney stones," Nature Reviews Disease Primers, vol. 2, p. 16008, 2016.

[11] P. M. Ferraro, A. D'Addessi, and G. Gambaro, "Randall's plaques, plugs and the clinical workup of the renal stone patient," Urolithiasis, vol. 43, no. 1, pp. 59-61, 2015.

[12] G. Gambaro, E. Croppi, F. Coe et al., "Metabolic diagnosis and medical prevention of calcium nephrolithiasis and its systemic manifestations: a consensus statement," Journal of Nephrology, vol. 29, no. 6, pp. 715-734, 2016.
[13] A. E. Krambeck, S. E. Handa, A. P. Evan, and J. E. Lingeman, "Profile of the brushite stone former," Journal of Urology, vol. 184, no. 4, pp. 1367-1371, 2010.

[14] K. Sakhaee, "Epidemiology and clinical pathophysiology of uric acid kidney stones," Journal of Nephrology, vol. 27, no. 3, pp. 241-245, 2014.

[15] L. Maurice-Estepa, P. Levillain, B. Lacour, and M. Daudon, "Crystalline phase differentiation in urinary calcium phosphate and magnesium phosphate calculi," Scandinavian Journal of Urology and Nephrology, vol. 33, no. 5, pp. 299-305, 1999.

[16] C. Martelli, V. Marzano, F. Iavarone et al., "Characterization of the protein components of matrix stones sheds light on S100-A8 and S100-A9 relevance in the inflammatory pathogenesis of these rare renal calculi," Journal of Urology, vol. 196, no. 3, pp. 911-918, 2016.

[17] A. Urbani, S. Lupisella, V. Sirolli et al., "Proteomic analysis of protein adsorption capacity by different haemodialysis membranes," Molecular Biosystem, vol. 8, no. 4, pp. 10291039, 2012.

[18] C. Kristensen, J. H. Parks, M. Lindheimer, and F. L. Coe, "Reduced glomerular filtration rate and hypercalciuria in primary struvite nephrolithiasis," Kidney International, vol. 32, no. 5, pp. 749-753, 1987.

[19] M. Daudon, H. Bouzidi, and D. Bazin, "Composition and morphology of phosphate stones and their relation with etiology," Urological Research, vol. 38, no. 6, pp. 459-467, 2010.

[20] A. E. Krambeck, S. E. Handa, A. P. Evan, and J. E. Lingeman, "Brushite stone disease as a consequence of lithotripsy?," Urological Research, vol. 38, no. 4, pp. 293-299, 2010.

[21] A. P. Evan, J. E. Lingeman, E. M. Worcester et al., "Contrasting histopathology and crystal deposits in kidneys of idiopathic stone formers who produce hydroxy apatite, brushite, or calcium oxalate stones," Anatomical Record, vol. 297, no. 4, pp. 731-748, 2014.

[22] J. Cloutier, L. Villa, O. Traxer, and M. Daudon, "Kidney stone analysis: "give me your stone, I will tell you who you are!", " World Journal of Urology, vol. 33, no. 2, pp. 157-169, 2015.

[23] L. Nazzal, S. Puri, and D. S. Goldfarb, "Enteric hyperoxaluria: an important cause of end-stage kidney disease," Nephrology Dialysis Transplantation, vol. 31, no. 3, pp. 375-382, 2016.

[24] A. Dessombz, E. Letavernier, J. P. Haymann, D. Bazin, and M. Daudon, "Calcium phosphate stone morphology can reliably predict distal renal tubular acidosis," Journal of Urology, vol. 193, no. 5, pp. 1564-1569, 2015. 

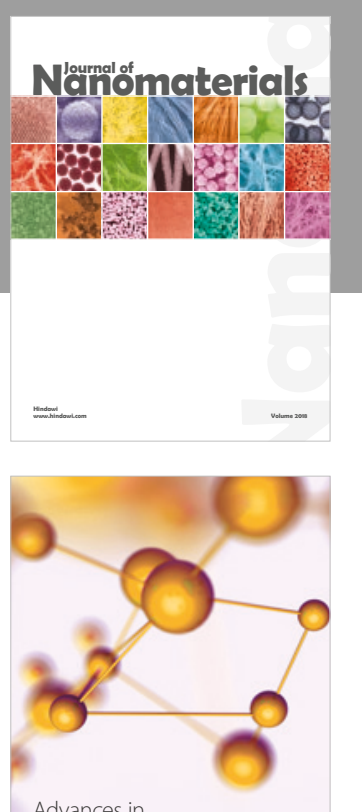

Physical Chemistry
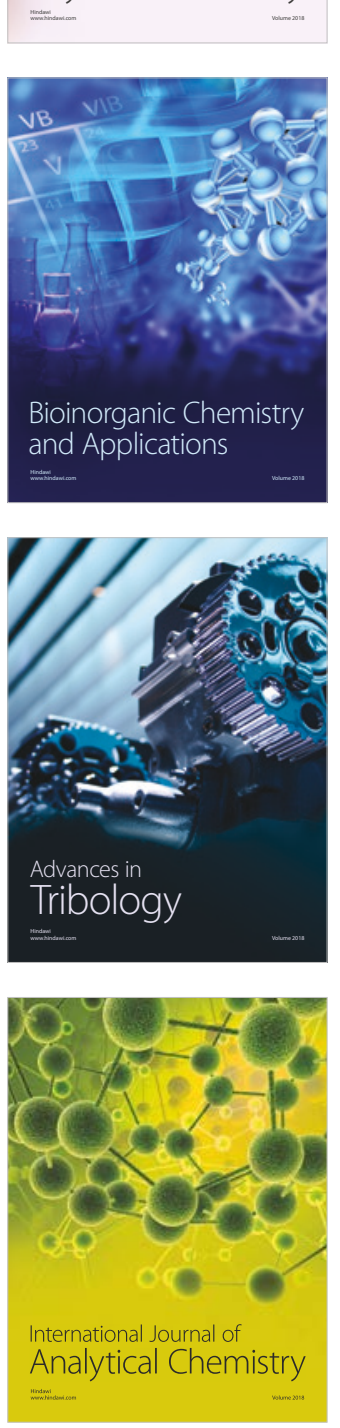

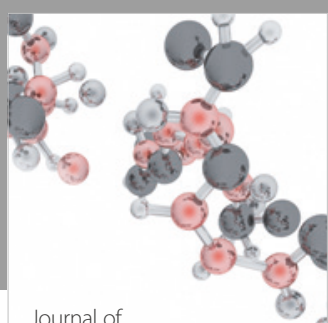

Analytical Methods

in Chemistry

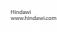

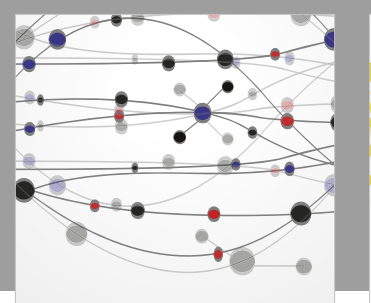

The Scientific World Journal

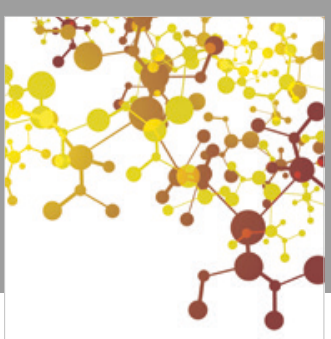

Journal of

Applied Chemistry
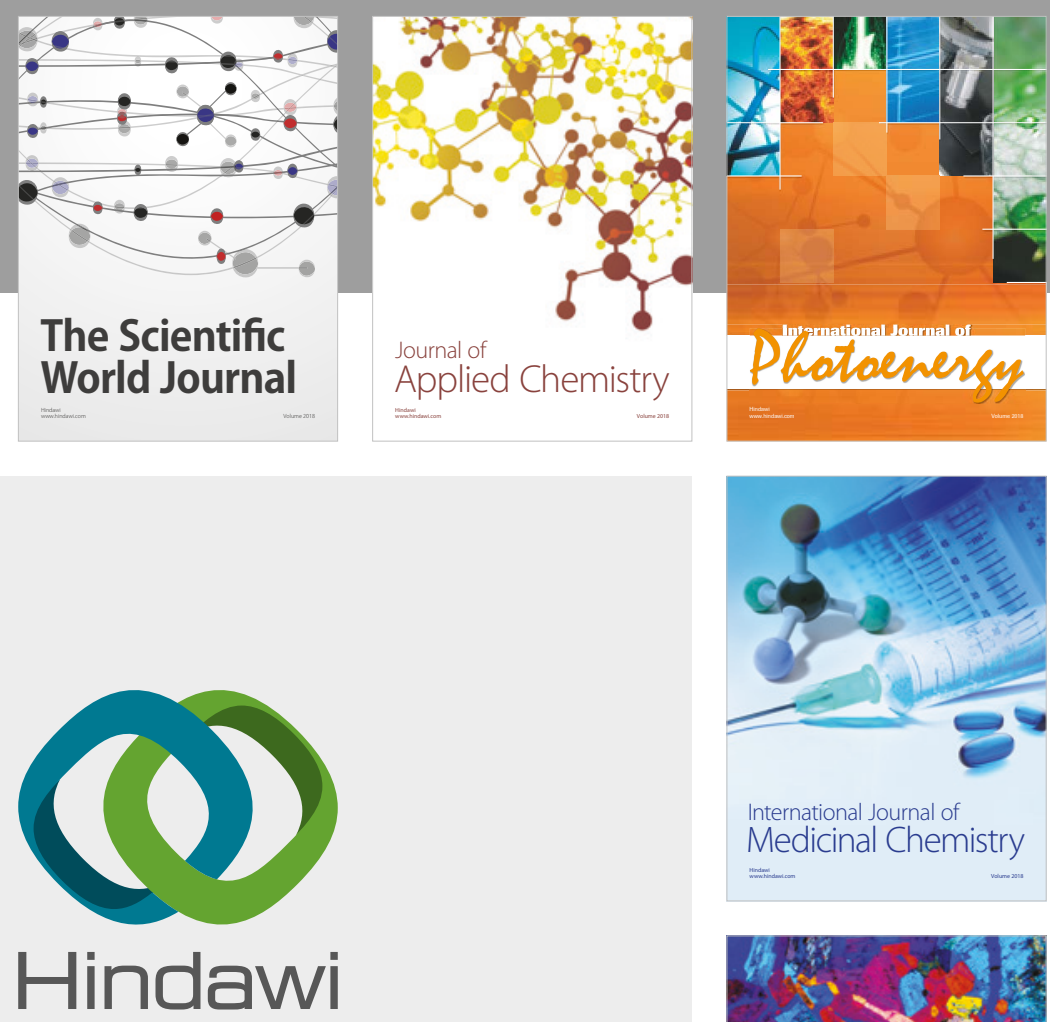

Submit your manuscripts at

www.hindawi.com
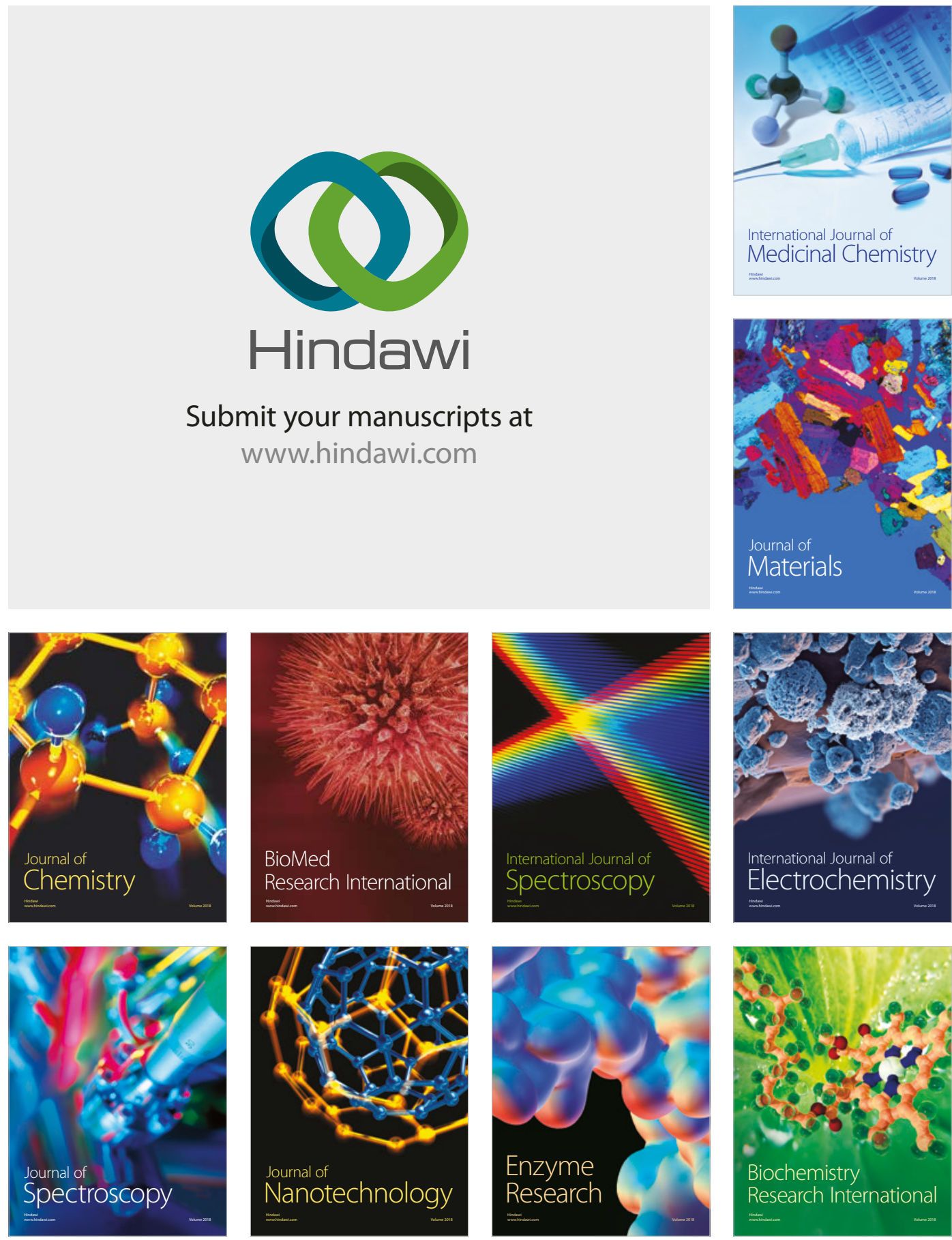
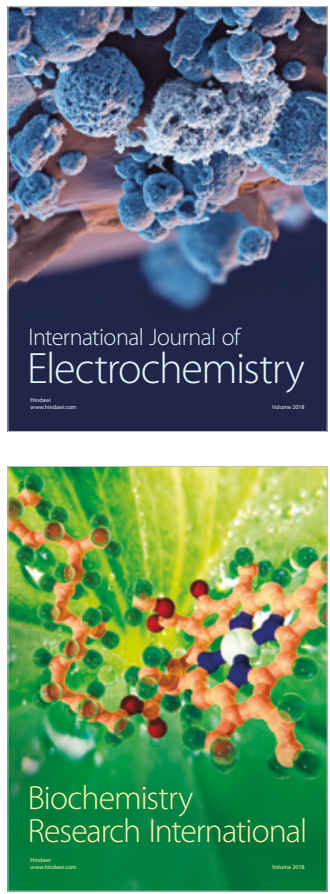